\title{
DO COUNTRIES IMPORT CORRUPTION? A MICRO ANALYSIS OF RUSSIA'S TRADE PARTNERS IN EASTERN EUROPE AND CENTRAL ASIA
}

\author{
Felicia Belostecinic \\ Georgetown University, Washington D.C.
}

\begin{abstract}
This paper uses a probit and dprobit model to examine the domestic determinants of corruption in Eastern Europe and Central Asia. Furthermore, it looks at whether economic links with a country that is perceived as corrupt - Russia - leads to an increase or decrease in the level of domestic corruption. Using a dataset at the firm level provided by the World Bank, this paper finds that the "Control Rights Hypothesis," the "Bargaining Power Hypothesis", and the "Grease the Wheels Hypothesis" are statistically significant at the domestic level and also shows that increased commerce links with Russia are a statistically significant determinant for corruption, thereby further supporting the "Grease the Wheels Hypothesis" hypothesis.
\end{abstract}

Keywords: Corruption, trade, Probit, Dprobit, Microanalysis.

DOI: http://dx.doi.org/10.15549/jeecar.v4i1.150

\section{INTRODUCTION}

Corruption, defined by Transparency International as the abuse of entrusted power for private gain, is a phenomenon that directly impedes reform and economic development in any society. The most common form of corruption is bribery, whereby an official demands informal payments to perform an official task or to influence legislation (legal or illegal forms of lobbying). On an international scale, rampant domestic corruption can lead to low attractiveness for foreign investors and international trade partners. On a domestic level, corruption can lead to an unstable economic and political system, the growth of shadow economies, manipulation of prices, and the unfair distribution of income and social benefits. Whereas the consequences of corruption are widely understood, there remains significant debate as to what are the exact determinants of corruption-and how domestic and international factors interact to either facilitate or prevent corruption. In an attempt to better understand these determinants of corruption, this paper will examine three hypotheses that explain the causes of corruption - the "Control Rights Hypothesis," the "Bargaining Power Hypothesis", and the "Grease the Wheels Hypothesis" - in the context of trade relations with a country that is perceived as corrupt, namely with the Russian Federation.

\section{LITERATURE REVIEW}

Alaimo et al. (2009) discusses three hypotheses that may explain the determinants of corruption and created an econometric model that allows to incorporate aspects related to the 
"Control Rights hypothesis" (where regulations give public officials extensive discretionary power to extract bribes from firms), the "Bargaining Power hypothesis" (where more profitable firms have more incentive to pay bribes), and the "Grease the Wheels hypothesis" (where firms have incentives to bribe officials perhaps to skip regulation or to secure a contract). Their paper finds evidence for the first and the third of these hypotheses but much less for the second, with the possible exception of small firms.

Alaimo et al. draw on Svensson (2003), who explains the incidence of corruption through the amount of regulation across industries ("control rights" hypothesis) and by the crucial role of a firm's ability to pay and the subsequent influence on its bargaining position. There is however ample debate regarding the "Grease the Wheels" hypothesis (Aidt 2009). Those in favor argue that corruption facilitates forms of trade that wouldn't have occurred otherwise and that it therefore enables private sector actors to circumvent cumbersome regulation. (Méon and Weill, 2010). Those that are opposed argue that offering a bribe is only due to the bad institutional setting and that it would be necessary to first recognize the endogeneity of institutions and trade (Aidt, 2009).

In the context of the Soviet Union and more recently Russia, William Clark (1993) has enumerated some of the positive aspects of corruption in the USSR. In his view, corruption, among other functions, encouraged capital formation, reduced bureaucratic rigidity, promoted entrepreneurial behavior, substituted economic activity for political violence, and attracted quality personnel to government service. This view directly exemplifies the "Grease the Wheels Hypothesis" -i.e. that bribes are a means of overcoming a cumbersome legislative system. Strangely enough, although corruption was explained as a structural dysfunction of the communist system, the focus in post-Soviet Russia shifted, and it is now mainly perceived as a reflection of individual values. Corruption has spread in postSoviet Russia as a result of what Jeffrey Jordan (2002) calls the "post-communist malaise" that affects all countries undergoing postcommunist transitions. Vadim Radaev (2000) has further argued that, in Russia, corruption is a well-established institution, rather than a deviation from the norm, and should be studied as such. Successive failures in combating organized corruption have shown that a proper response to the phenomenon in Russia should be sought in complex measures articulated simultaneously around a restructuring of political beliefs and a reform of Russia's governance. In the context of private firms, Blagojevic and Damijan (2013) find that private firms (domestic and foreign-owned) are more involved in both informal payments and state capture.

This study will therefore address a gap in existing literature on corruption by specifically analyzing the endogenous factors that Aidt (2009) mentions-that of trade. By specifically focusing on the impact of trade with Russia, this paper explores whether economic ties with a country that is already perceived as corrupt actually leads to an overflow of corruption into the home economy, and whether this adversely affects the behavior of domestic firms and increases their own likelihood of giving a bribe themselves.

\section{METHODOLOGY}

This paper's main finding is that a firm which is located in a country with export relations with Russia that are higher than the group average is more likely to pay a bribe even though it believes its own domestic judicial system to be effective-effectively proving the "Grease the Wheels Hypothesis" in the context of trade with a corrupt country. As a roadmap, this paper will first present an introduction to corruption in Eastern Europe and Central Asia, followed by an empirical analysis, and will conclude with policy implications.

The individual unit of analysis is the firm. The rationale for examining firms in Eastern Europe and Central Asia lies in the fact that the private sector plays a significant role in the functioning of societies and represents a pivotal actor in private-public relations. In the case of Eastern Europe and Central Asia, 19 countries have a Corruption Perception Index below 4 (out of 10), and 11 countries are ranked above 100 out of 180 countries surveyed (Table 1 ) - demonstrating a region-wide corruption problem. 
Table 1. Corruption Perception Index

\begin{tabular}{lcc}
\hline Country & CPI score & CPI rank \\
\hline Albania & 3.2 & 95 \\
Armenia & 2.7 & 120 \\
Azerbaijan & 2.3 & 143 \\
Belarus & 2.4 & 139 \\
Bosnia and & 3.0 & 99 \\
Herzegovina & 3.8 & 71 \\
Bulgaria & 4.1 & 66 \\
Croatia & 4.9 & 52 \\
Czech Republic & 6.6 & 27 \\
Estonia & 3.8 & 71 \\
FYR Macedonia & 4.1 & 66 \\
Georgia & 8.0 & 14 \\
Germany & 5.1 & 46 \\
Hungary & 2.7 & 120 \\
Kazakhstan & 3.3 & 103 \\
Kosovo & 1.9 & 162 \\
Kyrgyz Republic & 4.5 & 56 \\
Latvia & 4.9 & 52 \\
Lithuania & 3.3 & 89 \\
Moldova & 2.7 & 120 \\
Mongolia & 3.9 & 69 \\
Montenegro & 5.0 & 49 \\
Poland & 3.8 & 71 \\
Romania & 2.2 & 146 \\
Russia & 3.5 & 83 \\
Serbia & 4.5 & 56 \\
Slovak Republic & 6.6 & 27 \\
Slovenia & 2.0 & 158 \\
Tajikistan & 4.4 & 61 \\
Turkey & 2.2 & 146 \\
Ukraine & 1.7 & 174 \\
Uzbekistan & \\
\hline \hline Source & 36 \\
\hline
\end{tabular}

Source: Transparency International.

Yet the region also holds interesting political, economic and social variation, making it an ideal location to study the determinants of corruption at both national and international levels. It is therefore specifically in this region that the impact of globalization on corporate activity implies that a company is affected by more than just national legislation. It becomes necessary to examine whether a firm will pay bribes only due to interactions of the home government with the firm itself, or whether the international agreements and economic ties entered by the home government also impact the likelihood of domestic firms paying a bribe.

In order to establish whether such economic relations impact domestic firms, it is necessary to examine trade relations with a country that is perceived as corrupt, is a regional political and economic power, and also has substantive economic relations with countries throughout Eastern Europe and Central Asia-and the Russian Federation meets all of these criteria. Russia's CPI rank for 2009, as suggested by Transparency International, is 146 out of 180 surveyed (Table 1). Other research in 2009 showed that $29 \%$ of citizens and $56 \%$ of business people had paid a bribe (FOM 2008). Although Russia does not hold the lowest rank in the region, it is ranked in the bottom five of countries analyzed in this paper. Russia is therefore not only a pivotal economic player in the region, but is also one that is overwhelmingly perceived as corrupt.

Economic ties are defined as the percentage of exports from the home country to Russia. Of the 31 countries in the data set, 12 countries export more than $5 \%$ of their total exports to Russia, with an average of $7.34 \%$ for the whole data set. The rationale for choosing exports to Russia as a measurement of economic ties lies in the fact that Russia often uses a ban on imports as retaliatory measures against governments it wishes to intimidate (Kutlina-Dimitrova, 2013). A willingness to accept imports from a country is therefore used as a proxy for indicating "friendly" political and economic ties between Russia and the exporting country.

In order to guarantee robustness for the chosen independent variable, this paper will also include a proxy for economic links: Foreign Direct Investment (FDI). Russia's total FDI outflow to the 31 countries in the data set is $\$ 7.6$ bln for 2009 (Table 2). FDI has long been a measurement of marked expansion of international production by transnational corporations and represents a valuable source of financing for firms in the home economy. Yet in a survey of more than 390 senior business executives, almost $45 \%$ said that they had decided not to pursue a business because of the risk of corruption in the destination country (PWC 2008). 
Table 2. Breakdown of Exports, FDI and Country Fixed Effects

\begin{tabular}{|c|c|c|c|c|c|}
\hline Country & $\begin{array}{c}\text { Exports to Russia } \\
\text { as share of total } \\
\text { exports }\end{array}$ & $\begin{array}{l}\text { Russian FDI } \\
\text { outflow to } \\
\text { country, } \\
\text { in \$U.S. mln }\end{array}$ & $\begin{array}{l}\text { Eurasian } \\
\text { Economic } \\
\text { Unit }\end{array}$ & $\begin{array}{c}\text { Commonwealth } \\
\text { of Independent } \\
\text { States }\end{array}$ & $\begin{array}{l}\text { Former } \\
\text { Soviet } \\
\text { Union }\end{array}$ \\
\hline Albania & $0.01 \%$ & $\mathrm{n} / \mathrm{a}$ & & & \\
\hline Armenia & $15.65 \%$ & 178.91 & $\mathrm{x}$ & $\mathrm{x}$ & $\mathrm{x}$ \\
\hline Azerbaijan & $5.07 \%$ & 269.19 & & $\mathrm{x}$ & $\mathrm{x}$ \\
\hline Belarus & $31.54 \%$ & 122.36 & $\mathrm{x}$ & $\mathrm{x}$ & $\mathrm{x}$ \\
\hline $\begin{array}{l}\text { Bosnia and } \\
\text { Herzegovina }\end{array}$ & $0.46 \%$ & 286.67 & & & \\
\hline Bulgaria & $2.54 \%$ & 260.89 & & & \\
\hline Croatia & $1.47 \%$ & 12.93 & & & \\
\hline Czech Republic & $2.32 \%$ & 141.52 & & & \\
\hline Estonia & $17.05 \%$ & 10.57 & & & $\mathrm{x}$ \\
\hline FYR Macedonia & $0.84 \%$ & $\mathrm{n} / \mathrm{a}$ & & & \\
\hline Georgia & $1.81 \%$ & -7.61 & & & $\mathrm{x}$ \\
\hline Germany & $2.54 \%$ & 1488.15 & & & \\
\hline Hungary & $3.53 \%$ & 1788.67 & & & \\
\hline Kazakhstan & $8.21 \%$ & 1028.80 & $\mathrm{x}$ & $\mathrm{x}$ & $\mathrm{x}$ \\
\hline Kosovo & $0.01 \%$ & 0.00 & & & \\
\hline Kyrgyz Republic & $15.75 \%$ & $\mathrm{n} / \mathrm{a}$ & $\mathrm{x}$ & $\mathrm{x}$ & $\mathrm{x}$ \\
\hline Latvia & $8.78 \%$ & 78.20 & & & $\mathrm{x}$ \\
\hline Lithuania & $13.27 \%$ & 64.14 & & & $\mathrm{x}$ \\
\hline Moldova & $22.33 \%$ & 110.27 & & $\mathrm{x}$ & $\mathrm{x}$ \\
\hline Mongolia & $3.80 \%$ & 49.25 & & & \\
\hline Montenegro & $0.55 \%$ & 84.77 & & & \\
\hline Poland & $3.67 \%$ & 13.10 & & & \\
\hline Romania & $1.76 \%$ & 38.70 & & & \\
\hline Russia & $\mathrm{n} / \mathrm{a}$ & $\mathrm{n} / \mathrm{a}$ & $\mathrm{x}$ & & $\mathrm{x}$ \\
\hline Serbia & $4.19 \%$ & 609.43 & & & \\
\hline Slovak Republic & $3.56 \%$ & 7.05 & & & \\
\hline Slovenia & $3.27 \%$ & 1.90 & & & \\
\hline Tajikistan & $5.00 \%$ & 13.85 & & $\mathrm{x}$ & $\mathrm{x}$ \\
\hline Turkey & $3.14 \%$ & 106.20 & & & \\
\hline Ukraine & $21.15 \%$ & 677.59 & & $\mathrm{x}$ & $\mathrm{x}$ \\
\hline Uzbekistan & $17.00 \%$ & 217.01 & & $\mathrm{x}$ & $\mathrm{x}$ \\
\hline
\end{tabular}

\section{DATA ANALYSIS}

This paper will use the Business Environment and Enterprise Performance Survey (BEEPS) firm-level panel data for Eastern Europe and Central Asia for the year 2009. Table 3 lists all countries in the analysis and offers the breakdown of number of participating firms from each country.

BEEPS also details five aspects of corruption as perceived by firms: (1) corruption as an obstacle to business, (2) frequency of informal payments, (3) size of the 'bribe tax', (4) managers' perception of the impact of state capture on the firm, and (5) the extent of firms' direct participation in state capture.

The dependent variable, bribe, is defined as a dummy variable measuring if an informal payment or gift was expected for electrical, water, or telephone connections, construction permits, operating or importing licenses, or government contracts. Table 4 shows the breakdown of reported instances of bribe in each country. 
Table 3. Number of Respondent Firms per Country

\begin{tabular}{lcc}
\hline Country & $\begin{array}{c}\text { Number of } \\
\text { firms }\end{array}$ & $\begin{array}{c}\text { Number of firms as } \\
\text { percent of total } \\
\text { observations }\end{array}$ \\
\hline Albania & 175 & $1.50 \%$ \\
Armenia & 374 & $3.21 \%$ \\
Azerbaijan & 380 & $3.26 \%$ \\
Belarus & 273 & $2.34 \%$ \\
Bosnia and & 361 & $3.09 \%$ \\
Herzegovina & 288 & $2.47 \%$ \\
Bulgaria & 159 & $1.36 \%$ \\
Croatia & 250 & $2.14 \%$ \\
Czech Republic & 273 & $2.34 \%$ \\
Estonia & 366 & $3.14 \%$ \\
FYR Macedonia & 373 & $3.20 \%$ \\
Georgia & 291 & $2.49 \%$ \\
Hungary & 544 & $4.66 \%$ \\
Kazakhstan & 270 & $2.31 \%$ \\
Kosovo & 235 & $2.01 \%$ \\
Kyrgyz Republic & 271 & $2.32 \%$ \\
Latvia & 276 & $2.37 \%$ \\
Lithuania & 363 & $3.11 \%$ \\
Moldova & 362 & $3.10 \%$ \\
Mongolia & 116 & $0.99 \%$ \\
Montenegro & 455 & $3.90 \%$ \\
Poland & 541 & $4.64 \%$ \\
Romania & 1,004 & $8.60 \%$ \\
Russia & 388 & $3.33 \%$ \\
Serbia & 275 & $2.36 \%$ \\
Slovak Republic & 276 & $2.37 \%$ \\
Slovenia & 360 & $3.09 \%$ \\
Tajikistan & 3652 & $9.87 \%$ \\
Turkey & 11,668 & $3.14 \%$ \\
Ukraine & & $100.00 \%$ \\
Uzbekistan & 356 & \\
\hline Total & 356 & \\
\hline \hline
\end{tabular}

Alaimo et al. set forward three hypotheses for the independent variables which are the domestic determinants of corruption: "control rights," "bargaining power," and "grease the wheels."

Regulatory compliance ("Control Rights Hypothesis") is coded as a dummy variable public - measuring if the firm obtained an electrical, water, or telephone connection, construction permit, or operating or importing license. The degree of regulatory compliance is used as a proxy for the quantity and quality of regulations and would thus capture the forces underlying the control rights hypothesis.
Regulatory differences are expected to explain why public officials in certain sectors or agencies can extract rents more easily than in others. Alaimo et al.'s hypothesis is therefore that higher compliance will be associated with less frequent bribe payments. Furthermore, a variable is introduced for the number of times the firm was visited by tax inspectors in the previous fiscal year. This variable measures the degree of regulatory enforcement. 
Table 4. Breakdown of Instances of Bribe by Country

\begin{tabular}{lcc}
\hline Country & $\begin{array}{c}\text { Reported } \\
\text { cases of bribe }\end{array}$ & Reported instances of bribe as share of total \\
\hline Albania & 39 & $22 \%$ \\
Armenia & 75 & $20 \%$ \\
Azerbaijan & 121 & $32 \%$ \\
Belarus & 37 & $14 \%$ \\
Bosnia and Herze & 39 & $11 \%$ \\
Bulgaria & 21 & $7 \%$ \\
Croatia & 26 & $16 \%$ \\
Czech Republic & 34 & $14 \%$ \\
Estonia & 15 & $5 \%$ \\
FYR Macedonia & 50 & $14 \%$ \\
Georgia & 19 & $5 \%$ \\
Hungary & 18 & $6 \%$ \\
Kazakhstan & 145 & $27 \%$ \\
Kosovo & 18 & $7 \%$ \\
Kyrgyz Republic & 94 & $40 \%$ \\
Latvia & 46 & $17 \%$ \\
Lithuania & 42 & $15 \%$ \\
Moldova & 104 & $29 \%$ \\
Mongolia & 171 & $47 \%$ \\
Montenegro & 16 & $14 \%$ \\
Poland & 35 & $8 \%$ \\
Romania & 81 & $15 \%$ \\
Russia & 331 & $33 \%$ \\
Serbia & 85 & $22 \%$ \\
Slovak Republic & 28 & $10 \%$ \\
Slovenia & 14 & $5 \%$ \\
Tajikistan & 164 & $46 \%$ \\
Turkey & 162 & $14 \%$ \\
Ukraine & 235 & $28 \%$ \\
Uzbekistan & 192 & $52 \%$ \\
\hline Total & 2457 & \\
\hline \hline & & \\
\hline
\end{tabular}

Access to finance ("Bargaining Power Hypothesis") is coded as a dummy variable bank - measuring if the firm has an overdraft facility, line of credit, or loan from a financial institution. This variable is included to measure the bargaining power of the firm, in other words whether the firm has access to credit in the financial sector. This would give an idea of the solvency of the firm, and hence of its future profitability. It is measured as a dummy variable that equals one if the firm has a loan, credit line, or overdraft facility or if the firm does not need any credit. If the bargaining hypothesis holds, Alaimo expects both variables would be expected to carry negative coefficients.

Trust in courts ( "Grease the Wheel Hypothesis") is coded as a dummy variable - court - measuring if the firm finds the court system fair, impartial, and uncorrupted. An additional variable is included to account for this hypothesis: a dummy variable for foreignowned firms, in line with the idea that domestic firms have better information about the integrity of public officials and may have lower ethical standards about corruption. Alaimo expects that if a firm finds the court system fair, it is less likely to give a bribe.

The main contribution of this paper is to take Alaimo et al.'s model and expand it to examine whether the reported instances of bribe at the micro level are determined by the economic agreements entered by the national government. Specifically, these economic ties are defined as a dummy variable that indicates 
whether the country has exports that exceed the $7.34 \%$ out of total exports as exports to Russia and an additional proxy of FDI flows higher than the $\$ 283 \mathrm{mln}$ average FDI inflows from Russia. The two variables are coded as russiatrade and $r_{-}$outflow respectively. Data regarding exports and FDI flows is gathered from the United Nations Conference on Trade and Development for 2009. Table 2 shows Russia's total FDI outflow to the 31 countries in the data set-\$7.6bln for 2009. Furthermore, of the 31 countries in the data set, 12 countries export more than $5 \%$ of their total exports to Russia, while the average stands at $7.34 \%$ for the whole data set.

In order to examine this hypothesis, this paper explores interaction terms between the three national determinants of corruption - "Control Rights," "Bargaining," and "Grease the Wheels" and russiatrade. An additional variable represents an interaction term between whether the firm is an exporter and whether the firm is located in the country that experiences above average trade with Russia. The FDI proxy is interacted with whether a firm is foreign owned. In order to be able to interact the term russiatrade and $r_{-}$outflow and keep the country fixed effects, this paper relies on a previous model by Hellman et al. (2003) where the authors include the interaction term with a full set of country dummies and excluded the capture economy dummy. The general rule for including interaction terms is to include both the interaction term plus the two components of the interaction term in a regression, i.e.

$$
y=\alpha+\beta X+\beta Z+\beta X Z+\varepsilon
$$

However, in the case of this research - as was the case for Hellman et al (2003) - the regression includes the full set of state dummies in place of russiatrade. By removing russiatrade, n-1 of the country fixed effects appear in the results. Because omitted variable bias is much larger if not controlling for a full set of country fixed effect, leaving out russiatrade is the more robust option.

Finally, at the domestic level, a set of controls are used for the regressions to account for observable and unobservable firm specific details. Region fixed effects cannot be included due to the nature of the region of Eastern Europe and Central Asia: many of the countries in the sample have such a small population that sample attrition might make some of the samples for individual regions minuscule. Therefore, in order to eliminate the issue of collinearity which can lead to omitted variable bias, this paper includes instead city dummiesfor capital city, city with population of over 1 million, with population of 250,000 to 1 million, population of 50,000 to 250,000 , and population of less than 50,000. In addition to country and industry fixed effects, this study includes the (log) age of the firm as well as dummy variables for exporters, small firms (1-20 employees), medium firms (20 to 100 employees), and large firms (more than 100 employees). As mentioned previously, this paper will also include a variable that indicates the number of inspections to which a firm was subjected in the previous year and whether the firm was created as a start-up or by privatizing a state-owned enterprise.

In order to use the country level controls and determine whether national level economic ties with Russia lead to more instances of corruption reported by firms in the home country, this paper relies on the following econometric model used by Alaimo et al:

$$
\operatorname{Pr}(\text { bribe })_{c, r}=\beta_{o}+\phi X_{c r}+\beta_{c}+\beta_{r}+\varepsilon_{c r}
$$

Where $\mathrm{c}=$ country; $\mathrm{r}=$ region are fixed effects. $\operatorname{Pr}($ bribe $)$ is the probability that the firm in question pays bribes, and $\mathrm{X}$ is a set of controls aimed at testing the national determinants of corruption. An analytical model is derived for each of the three major hypotheses, and a fourth equation includes all three hypotheses at the same time.

\section{RESULTS}

Table 5 reports the main findings for the pooled probit regressions. Column (1) analyses the baseline regression for the "Control Rights Hypothesis" with all aforementioned variables included in the regression. The baseline regression shows that firms which obtained an electrical, water, or telephone connection, construction permit, or operating or importing license are $13.6 \%$ more likely to pay a bribe than those which have not. This result contradicts the direction and the results predicted by Alaimo et al. who find that the amount and variation of regulation, as captured by the degree of regulatory compliance, is negatively associated with the probability of paying bribes. 
Column (3) analyses the baseline regression for the "Access to Finance Hypothesis" with all aforementioned variables included in the regression. The baseline regression shows that firms that have an overdraft facility, line of credit, or loan from a financial institution do have access to finance are $8.8 \%$ more likely to pay a bribe. This again contradicts the results presented by Alaimo et al. who predict a negative coefficient.

Column (5) analyses the baseline regression for the "Grease the Wheels" hypothesis with all aforementioned variables included in the regression. Firms that that find the court system fair and impartial are $7.9 \%$ less likely to pay a bribe than firms that do not find the court system to be fair. The direction of these findings coincides with Alaimo et al.'s findings and are statistically significant.

Columns (7) represents all three hypotheses interacted. The results maintain the statistical significance and the direction of each individual hypothesis.

Column (2) (and Columns (4), (6) and (8) respectively) represents a dprobit regression for the same hypothesis so as to interpret the elasticity of the relationship. Rather than reporting the coefficients, dprobit reports the marginal effect, that is, the change in the probability for an infinitesimal change in each independent, continuous variable and, by default, reports the discrete change in the probability for dummy variables (i.e., going from 0 to 1 ). As expected, the results of Columns (2) ((4), (6) and (8)) correlate with the variables in the adjacent columns.

For all three hypotheses, the variable indicating firm size is statistically significant and the effect is negative, indicating that medium firms are 3.8\% less likely to pay a bribe than a small firm when having access to publicly provided services and that under the same circumstances, large firms are $4.6 \%$ less likely to pay a bribe than small firms. Whether a firm was foreign owned provided no statistical significance, contradictory to the results presented by Alaimo et al. Interestingly, inspections do prove to be statistically significant and have a positive coefficient: firms that reported more than 30 inspections in the previous years are $15.7 \%$ more likely to pay bribes (under all three hypotheses interacted) than firms that reported under 10 inspections in the previous year. The statistical significance of whether a firm is located in the capital is significant at the $1 \%$ level for all three hypotheses interacted, and indicates that firms that are located in the capital city are 5.21\% more likely to report a bribe. Whether the firm is an exporter is not statistically significant in the case of all three hypotheses. Furthermore, if a firm was created by privatizing a state-owned enterprise, the firm was 3.56\% less likely to have reported giving a bribe.

The additional proxy for measurement of economic relations, that of FDI flows, also proved to be statistically significant and positive across all three hypotheses. Due to lack of availability of data, it is not possible to examine whether each firm actually was a recipient of Russian FDI, but the interaction with the foreign variable in the context of countries that have more trade with Russia is more likely to achieve that specification. Despite the narrow definition of the term, it still yields statistically significant results in the expected direction of the main IV, hence supporting the proposed hypothesis.

Table 6 follows the same structure of Table 5 and presents these results interacted with the external variable russiatrade. Column (1) indicates that endogenous trade relations with Russia do not affect the amount of bribe through the variation in the degree of access to finance. According to the results, firms that obtained an electrical, water, or telephone connection, construction permit, or operating or importing license are no more or less likely to pay a bribe if they are located in a country that has extensive trade relations with Russia.

Column (3) shows results for the baseline regression with the "Access to Finance Hypothesis" interacted with russiatrade. Again, these results are not statistically significant.

Column (5) analyses the baseline regression for the "Grease the Wheels" hypothesis. Firms that trust the court system and are located in countries that have above average trade with Russia are $10.9 \%$ more likely to pay bribes than firms that are not located in countries that have extensive trade relations with Russia, and these results are statistically significant. 
Table 5. National Level Determinants of Corruption

\begin{tabular}{|c|c|c|c|c|c|c|c|c|}
\hline VARIABLES & $\begin{array}{l}\text { Control Rights } \\
\text { probit } \\
\text { (1) }\end{array}$ & $\begin{array}{l}\text { Control rights } \\
\text { dprobit } \\
\text { (2) }\end{array}$ & $\begin{array}{l}\text { Bargaining } \\
\text { Power probit } \\
\text { (3) }\end{array}$ & $\begin{array}{c}\text { Bargaining } \\
\text { Power } \\
\text { dprobit } \\
(4)\end{array}$ & $\begin{array}{l}\text { Grease the } \\
\text { Wheels } \\
\text { probit } \\
(5)\end{array}$ & $\begin{array}{l}\text { Grease the } \\
\text { wheels } \\
\text { dprobit } \\
\text { (6) }\end{array}$ & $\begin{array}{l}\text { All three } \\
\text { probit } \\
\text { (7) }\end{array}$ & $\begin{array}{l}\text { All three } \\
\text { dprobit } \\
\text { (8) }\end{array}$ \\
\hline Regulatory Compliance & $\begin{array}{c}0.484^{* * *} \\
(-0.0454)\end{array}$ & $\begin{array}{c}0.136^{* * *} \\
(-0.0131)\end{array}$ & & & & & $\begin{array}{c}0.461^{* * *} \\
(-0.0466)\end{array}$ & $\begin{array}{c}0.128^{* * *} \\
(-0.0134)\end{array}$ \\
\hline Access to Finance & & & $\begin{array}{c}0.322^{* * *} \\
(-0.0475)\end{array}$ & $\begin{array}{c}0.0882^{* * *} \\
(-0.013)\end{array}$ & & & $\begin{array}{c}0.256^{* * *} \\
(-0.0487)\end{array}$ & $\begin{array}{c}0.0683^{* * *} \\
(-0.013)\end{array}$ \\
\hline Trust in courts & & & & & $\begin{array}{l}-0.306^{* * *} \\
(-0.0502)\end{array}$ & $\begin{array}{c}-0.0797^{* * *} \\
(-0.0124)\end{array}$ & $\begin{array}{l}-0.314^{* * *} \\
(-0.0512)\end{array}$ & $\begin{array}{c}-0.0799^{* * *} \\
(-0.0123)\end{array}$ \\
\hline The firm is foreign owned & $\begin{array}{c}-0.0361 \\
(-0.0602)\end{array}$ & $\begin{array}{l}-0.00954 \\
(-0.0157)\end{array}$ & $\begin{array}{c}-0.01 \\
(-0.0596)\end{array}$ & $\begin{array}{c}0.00 \\
(-0.0162)\end{array}$ & $\begin{array}{c}-0.01 \\
(-0.0591)\end{array}$ & $\begin{array}{c}-0.00298 \\
(-0.016)\end{array}$ & $\begin{array}{c}-0.0262 \\
(-0.0612)\end{array}$ & $\begin{array}{l}-0.0069 \\
(-0.016)\end{array}$ \\
\hline Firm is an exporter & $\begin{array}{c}0.0829 * \\
(-0.0489)\end{array}$ & $\begin{array}{c}0.0227^{*} \\
(-0.0136)\end{array}$ & $\begin{array}{c}0.0938^{*} \\
(-0.0489)\end{array}$ & $\begin{array}{l}0.0262^{*} \\
(-0.014)\end{array}$ & $\begin{array}{c}0.125^{* * *} \\
(-0.0483)\end{array}$ & $\begin{array}{l}0.0350^{* *} \\
(-0.0139)\end{array}$ & $\begin{array}{c}0.0673 \\
(-0.0495)\end{array}$ & $\begin{array}{c}0.0182 \\
(-0.0136)\end{array}$ \\
\hline Firm size: medium & $\begin{array}{c}-0.142^{* * *} \\
(-0.039)\end{array}$ & $\begin{array}{l}-0.0366^{* * *} \\
(-0.00966)\end{array}$ & $\begin{array}{l}-0.115^{* * *} \\
(-0.0389)\end{array}$ & $\begin{array}{l}-0.0306^{* * *} \\
(-0.00998)\end{array}$ & $\begin{array}{c}-0.0704^{*} \\
(-0.0385)\end{array}$ & $\begin{array}{l}-0.0188^{*} \\
(-0.0101)\end{array}$ & $\begin{array}{l}-0.151^{* * *} \\
(-0.0397)\end{array}$ & $\begin{array}{l}-0.0385^{* * *} \\
(-0.00971)\end{array}$ \\
\hline Firm size: large & $\begin{array}{l}-0.167^{* * *} \\
(-0.0457)\end{array}$ & $\begin{array}{c}-0.0425^{* * *} \\
(-0.011)\end{array}$ & $\begin{array}{l}-0.132^{* * *} \\
(-0.0461)\end{array}$ & $\begin{array}{c}-0.0346^{* * *} \\
(-0.0116)\end{array}$ & $\begin{array}{c}-0.06 \\
(-0.0451)\end{array}$ & $\begin{array}{c}-0.0166 \\
(-0.0118)\end{array}$ & $\begin{array}{l}-0.182^{* * *} \\
(-0.0468)\end{array}$ & $\begin{array}{c}-0.0457^{* * *} \\
(-0.0111)\end{array}$ \\
\hline Twenty Inspections & $\begin{array}{c}0.241^{* * *} \\
(-0.0576)\end{array}$ & $\begin{array}{l}0.0704^{* * *} \\
(-0.0182)\end{array}$ & $\begin{array}{c}0.263^{* * *} \\
(-0.0572)\end{array}$ & $\begin{array}{l}0.0787^{* * *} \\
(-0.0186)\end{array}$ & $\begin{array}{c}0.273^{* * *} \\
(-0.0569)\end{array}$ & $\begin{array}{l}0.0819 * * * \\
(-0.0185)\end{array}$ & $\begin{array}{c}0.224^{* * *} \\
(-0.0585)\end{array}$ & $\begin{array}{l}0.0647^{* * *} \\
(-0.0182)\end{array}$ \\
\hline Thirty Inspections & $\begin{array}{c}0.350^{* * *} \\
(-0.12)\end{array}$ & $\begin{array}{c}0.107^{* * *} \\
(-0.0411)\end{array}$ & $\begin{array}{c}0.400^{* * *} \\
(-0.12)\end{array}$ & $\begin{array}{c}0.127^{* * *} \\
(-0.0425)\end{array}$ & $\begin{array}{l}0.410^{* * *} \\
(-0.119)\end{array}$ & $\begin{array}{c}0.130^{* * *} \\
(-0.0425)\end{array}$ & $\begin{array}{c}0.339^{* * *} \\
(-0.12)\end{array}$ & $\begin{array}{c}0.103^{* *} \\
(-0.0406)\end{array}$ \\
\hline More than thirty Inspections & $\begin{array}{l}0.517^{* * *} \\
(-0.104)\end{array}$ & $\begin{array}{c}0.166^{* * *} \\
(-0.0382)\end{array}$ & $\begin{array}{l}0.597^{* * *} \\
(-0.101)\end{array}$ & $\begin{array}{c}0.199^{* * *} \\
(-0.0387)\end{array}$ & $\begin{array}{l}0.604^{* * *} \\
(-0.101)\end{array}$ & $\begin{array}{c}0.201^{* * *} \\
(-0.0383)\end{array}$ & $\begin{array}{l}0.492^{* * *} \\
(-0.103)\end{array}$ & $\begin{array}{c}0.157^{* * *} \\
(-0.0374)\end{array}$ \\
\hline Firm Located in the Capital & $\begin{array}{c}0.205^{* * *} \\
(-0.0452)\end{array}$ & $\begin{array}{l}0.0570^{* * *} \\
(-0.0131)\end{array}$ & $\begin{array}{c}0.198^{* * *} \\
(-0.0447)\end{array}$ & $\begin{array}{l}0.0560^{* * *} \\
(-0.0131)\end{array}$ & $\begin{array}{c}0.167^{* * *} \\
(-0.0445)\end{array}$ & $\begin{array}{l}0.0468 * * * \\
(-0.0129)\end{array}$ & $\begin{array}{c}0.189^{* * *} \\
(-0.0456)\end{array}$ & $\begin{array}{c}0.0521^{* * *} \\
(-0.013)\end{array}$ \\
\hline Firm Located in a Large City & $\begin{array}{c}0.223^{* * *} \\
(-0.0687)\end{array}$ & $\begin{array}{c}0.0641^{* * *} \\
(-0.021)\end{array}$ & $\begin{array}{c}0.234^{* * *} \\
(-0.0683)\end{array}$ & $\begin{array}{l}0.0687^{* * *} \\
(-0.0213)\end{array}$ & $\begin{array}{c}0.221^{* * *} \\
(-0.0678)\end{array}$ & $\begin{array}{l}0.0642^{* * *} \\
(-0.0209)\end{array}$ & $\begin{array}{l}0.224^{* * *} \\
(-0.069)\end{array}$ & $\begin{array}{c}0.0641^{* * *} \\
(-0.021)\end{array}$ \\
\hline Firm Located in a Medium City & $\begin{array}{l}-0.00705 \\
(-0.0568)\end{array}$ & $\begin{array}{l}-0.00188 \\
(-0.0151)\end{array}$ & $\begin{array}{c}-0.0221 \\
(-0.0556)\end{array}$ & $\begin{array}{c}-0.006 \\
(-0.015)\end{array}$ & $\begin{array}{c}-0.03 \\
(-0.0553)\end{array}$ & $\begin{array}{l}-0.00808 \\
(-0.0148)\end{array}$ & $\begin{array}{c}-0.0201 \\
(-0.0571)\end{array}$ & $\begin{array}{l}-0.0053 \\
(-0.015)\end{array}$ \\
\hline Firm Located in a Small City & $\begin{array}{c}0.0815^{*} \\
(-0.0485)\end{array}$ & $\begin{array}{c}0.0223^{*} \\
(-0.0135)\end{array}$ & $\begin{array}{c}0.0708 \\
(-0.048)\end{array}$ & $\begin{array}{c}0.0197 \\
(-0.0136)\end{array}$ & $\begin{array}{c}0.0567 \\
(-0.0479)\end{array}$ & $\begin{array}{c}0.0156 \\
(-0.0134)\end{array}$ & $\begin{array}{c}0.0614 \\
(-0.049)\end{array}$ & $\begin{array}{c}0.0166 \\
(-0.0135)\end{array}$ \\
\hline Company was privatized & $\begin{array}{l}-0.150^{* * *} \\
(-0.0412)\end{array}$ & $\begin{array}{c}-0.0385^{* * *} \\
(-0.0101)\end{array}$ & $\begin{array}{l}-0.179 * * * \\
(-0.041)\end{array}$ & $\begin{array}{c}-0.0465^{* * *} \\
(-0.0101)\end{array}$ & $\begin{array}{l}-0.186^{* * *} \\
(-0.0408)\end{array}$ & $\begin{array}{l}-0.0478^{* * *} \\
(-0.00991)\end{array}$ & $\begin{array}{l}-0.140^{* * *} \\
(-0.0417)\end{array}$ & $\begin{array}{c}-0.0356^{* * *} \\
(-0.0102)\end{array}$ \\
\hline Observations & 10,711 & 10,711 & 10,605 & 10,605 & 10,711 & 10,711 & 10,605 & 10,605 \\
\hline
\end{tabular}

Note: ${ }^{*}=$ significant at the 10 percent level; ${ }^{* *}=$ significant at the 5 percent level; ${ }^{* * *}=$ significant at the 1 percent level. Robust standard errors in parentheses.

The table reports the results of a probit and dprobit regression of the frequency of bribe payments on the variables in the first column. The dprobit coefficients reported correspond to marginal effects; that is, they reflect the (percentage) change in the probability of paying bribes if there is a one (percentage) point increase in the explanatory variable. All regressions include country and industry effects. 
Table 6. National Level Determinants of Corruption

\begin{tabular}{|c|c|c|c|c|c|c|c|c|}
\hline VARIABLES & $\begin{array}{c}\text { Control Rights } \\
\text { probit } \\
\text { (1) }\end{array}$ & $\begin{array}{l}\text { Control rights dprobit } \\
\text { (2) }\end{array}$ & $\begin{array}{c}\text { Bargaining Power } \\
\text { probit } \\
\text { (3) }\end{array}$ & $\begin{array}{l}\text { Bargaining } \\
\text { Power } \\
\text { dprobit } \\
(4)\end{array}$ & $\begin{array}{l}\text { Grease the } \\
\text { Wheels } \\
\text { probit } \\
\text { (5) }\end{array}$ & $\begin{array}{l}\text { Grease the } \\
\text { wheels } \\
\text { dprobit } \\
\text { (6) }\end{array}$ & $\begin{array}{l}\text { All three } \\
\text { probit } \\
(7)\end{array}$ & $\begin{array}{c}\text { All three } \\
\text { dprobit } \\
\text { (8) }\end{array}$ \\
\hline Regulatory Compliance & $\begin{array}{c}0.484^{* * *} \\
(-0.0454)\end{array}$ & $\begin{array}{c}0.136^{* * *} \\
(-0.0131)\end{array}$ & & & & & $\begin{array}{c}0.461^{* * *} \\
(-0.0466)\end{array}$ & $\begin{array}{c}0.128^{* * *} \\
(-0.0134)\end{array}$ \\
\hline Interaction with russiatrade & $\begin{array}{c}-0.0913 \\
(-0.0829)\end{array}$ & $\begin{array}{c}-0.0237 \\
(-0.0208)\end{array}$ & & & & & $\begin{array}{c}-0.11 \\
(-0.085)\end{array}$ & $\begin{array}{c}-0.0283 \\
(-0.0209)\end{array}$ \\
\hline Access to Finance & & & $\begin{array}{c}0.322^{* * *} \\
(-0.0475)\end{array}$ & $\begin{array}{c}0.0882^{* * *} \\
(-0.013)\end{array}$ & & & $\begin{array}{c}0.256^{* * *} \\
(-0.0487)\end{array}$ & $\begin{array}{c}0.0683^{* * *} \\
(-0.013)\end{array}$ \\
\hline Interaction with russiatrade & & & $\begin{array}{c}-0.02 \\
(-0.0851)\end{array}$ & $\begin{array}{c}0.00 \\
(-0.023)\end{array}$ & & & $\begin{array}{c}-0.0203 \\
(-0.0881)\end{array}$ & $\begin{array}{c}-0.0054 \\
(-0.0231)\end{array}$ \\
\hline Trust in courts & & & & & $\begin{array}{c}-0.306^{* * *} \\
(-0.0502)\end{array}$ & $\begin{array}{c}-0.0797^{* * *} \\
(-0.0124)\end{array}$ & $\begin{array}{l}-0.314^{* * *} \\
(-0.0512)\end{array}$ & $\begin{array}{c}-0.0799^{* * *} \\
(-0.0123)\end{array}$ \\
\hline Interaction with russiatrade & & & & & $\begin{array}{c}0.359^{* * *} \\
(-0.0889)\end{array}$ & $\begin{array}{c}0.109^{* * *} \\
(-0.0296)\end{array}$ & $\begin{array}{c}0.370^{* * *} \\
(-0.0917)\end{array}$ & $\begin{array}{c}0.111^{* * *} \\
(-0.0303)\end{array}$ \\
\hline Export*russiatrade & $\begin{array}{c}0.0945 \\
(-0.0821)\end{array}$ & $\begin{array}{c}0.0263 \\
(-0.0236)\end{array}$ & $\begin{array}{c}0.11 \\
(-0.0819)\end{array}$ & $\begin{array}{c}0.03 \\
(-0.0242)\end{array}$ & $\begin{array}{c}0.09 \\
(-0.0807)\end{array}$ & $\begin{array}{c}0.0265 \\
(-0.0235)\end{array}$ & $\begin{array}{c}0.0907 \\
(-0.0834)\end{array}$ & $\begin{array}{c}0.025 \\
(-0.0238)\end{array}$ \\
\hline The firm is foreign owned & $\begin{array}{c}-0.0361 \\
(-0.0602)\end{array}$ & $\begin{array}{l}-0.00954 \\
(-0.0157)\end{array}$ & $\begin{array}{c}-0.01 \\
(-0.0596)\end{array}$ & $\begin{array}{c}0.00 \\
(-0.0162)\end{array}$ & $\begin{array}{c}-0.01 \\
(-0.0591)\end{array}$ & $\begin{array}{c}-0.00298 \\
(-0.016)\end{array}$ & $\begin{array}{c}-0.0262 \\
(-0.0612)\end{array}$ & $\begin{array}{l}-0.0069 \\
(-0.016)\end{array}$ \\
\hline Foreign*russia_outflow & $\begin{array}{c}0.267^{* *} \\
(-0.107)\end{array}$ & $\begin{array}{l}0.0791^{* *} \\
(-0.0347)\end{array}$ & $\begin{array}{c}0.270^{* *} \\
(-0.106)\end{array}$ & $\begin{array}{c}0.0818^{* *} \\
(-0.0349)\end{array}$ & $\begin{array}{c}0.260^{* *} \\
(-0.105)\end{array}$ & $\begin{array}{l}0.0782^{* *} \\
(-0.0345)\end{array}$ & $\begin{array}{l}0.282^{* * *} \\
(-0.108)\end{array}$ & $\begin{array}{c}0.0839^{* *} \\
(-0.0353)\end{array}$ \\
\hline Moldova country fixed effect & $\begin{array}{c}0.254^{*} \\
(-0.136) \\
\end{array}$ & $\begin{array}{c}0.0749^{*} \\
(-0.0436) \\
\end{array}$ & $\begin{array}{l}0.372^{* * *} \\
(-0.137) \\
\end{array}$ & $\begin{array}{c}0.116^{* *} \\
(-0.0475) \\
\end{array}$ & $\begin{array}{c}0.229^{*} \\
(-0.132) \\
\end{array}$ & $\begin{array}{l}0.0680^{*} \\
(-0.041) \\
\end{array}$ & $\begin{array}{c}0.280^{*} \\
(-0.143) \\
\end{array}$ & $\begin{array}{c}0.0832^{*} \\
(-0.0465)\end{array}$ \\
\hline Observations & 10,711 & 10,711 & 10,605 & 10,605 & 10,711 & 10,711 & 10,605 & 10,605 \\
\hline
\end{tabular}

Note: ${ }^{*}=$ significant at the 10 percent level; ${ }^{* *}=$ significant at the 5 percent level; ${ }^{* * *}=$ significant at the 1 percent level.

Robust standard errors in parentheses.

The table reports the results of a probit and dprobit regression of the frequency of bribe payments on the variables in the first column. The dprobit coefficients reported correspond to marginal effects; that is, they reflect the (percentage) change in the probability of paying bribes if there is a one (percentage) point increase in the explanatory variable. All regressions include country and industry effects. 


\section{DISCUSSION OF RESULTS}

The results support the hypotheses regarding domestic determinants of corruption, and show how the latter are impacted by trade with Russia.

Macro level trade with Russia was shown to have no influence through the "Control Rights Hypothesis" or the "Bargaining Power Hypothesis" channels. At the domestic level of analysis, firms that have access to state provided licenses are more likely to pay a bribe-regardless of whether the country in which the firm was located traded extensively with Russia or not. The related hypotheses rest on the assumption that the implicit control that public officials exert on firms, coming from intrinsic features of regulations and from the unrestricted power of officials to enforce regulations, allows for them to exert substantial control over firms and to demand as well as obtain bribes. Furthermore, if a firm has a line of credit it is more likely to pay a bribe. Such firms are in a weaker bargaining position due to their high solvency as well as higher current and expected profits -the resources to pay more bribes. At the same time, higher future profits would also imply a higher exit price in terms of forgone profits. Both results actually contradict Alaimo's theory and provide new insights into domestic determinants of corruption. These findings, alongside the results for other firm level controls such as size, number of inspections, and origin of the firm point in the predicted direction. At the national level, they show a strong relation between the firm and the state, and indicate the causational determinants of corruption.

Yet trade with Russia did prove to have a statistical significance related to the "Grease the Wheels Hypothesis." A firm that believes that the court system is fair is less likely to pay a bribe, indicating that trust in the judicial system leads to a less corrupt firm. Yet trade with Russia seemed to have a positive and statistically significant effect on a firm's likelihood to give a bribe for firms that believe that the court system is fair. This finding could indicate in fact a very interesting mechanismthat the court system is considered fair because firms pay bribes to make sure that it upholds the firm's own interest. Such an assumption would be in line with the assumption of the "Grease the Wheels Hypothesis" that bribes are given in order to facilitate economic activity which would have otherwise been marred by an inefficient and corrupt legislative system.

\section{POLICY RECOMMENDATIONS}

Policy recommendations at the state level include strengthening the rule of law and providing transparency. Criminalizing bribe giving, restructuring outdated Civil Codes, Criminal Codes, Criminal Procedures and Civil Procedure Codes and the elaboration of a mechanism of implementation and control of implementation of such laws are key policy recommendations in countries that have weak institutional settings. However, there is little to no data that proves that solely devoting additional resources to the existing legal and financial government monitoring institutions will reduce corruption. (Svensson, 2005) Implementing increased monitoring alone is unlikely to reduce corruption in a country-it must come in combination with a set of other political reforms and hand in hand with the commitment of top officials to reduce bribetaking at the national level. All in all, the effectiveness of anticorruption policies hinges on the existence of an honest third party that can monitor the agent. Yet more importantly, whether such reforms can actually be carried out depends entirely on the willingness to eradicate corruption on the part of high-up public officials-otherwise the efforts will be completely contracted.

At the international level, numerous studies have shown that openness to trade and diversification of trade partners will reduce corruption. (Krueger 1974) In economically open and integrated countries, governments are able to circumvent domestic lobbying from actors that would have interests to prevent external competition. Such countries are able to subject their economy to more transparency and more international competition and as a result bring about all the national level reforms needed to reduce corruption. Openness to trade could also assure that the country enters international agreements to deter transnational corruption, hence eradicating corruption not only internally but also containing its spread across countries. Furthermore, laws against corruption abroad could deter countries from engaging in corrupt practices while in foreign countries. (Cuervo-Cazurra 2006) As a country increases its openness to trade and presents incentives to reduce corruption, it could then 
also attract more FDI in a virtuous cycle of reducing corruption.

\section{CONCLUSION}

The effects of corruption are not only economically stifling, but also represent a huge impediment towards social development. In a world that is becoming more and more globalized, and in which trade mechanisms become more and more complex, it is necessary to take into account how macroeconomic factors affect individual economic agents. In order to be able to correct for a distortive phenomenon such as corruption, it is necessary first and foremost to understand the causal mechanisms as well as the characteristics of each individual affected country.

This paper addressed a theoretical gap in the literature -the role of trade relations with a specific corrupt country. It examined whether economic relations with a corrupt country specifically with the Russian Federation would lead to more corruption at the firm level in Eastern Europe and Central Asia. Specifically, this paper has focused on examining countries that have reported above average exports to Russia and above average FDI inflows from Russia. At the domestic level, this paper used the model presented by Alaimo et al. and found that even though there was no strong empirical evidence for the "Control Rights" and "Bargaining Power Hypothesis," there is evidence supporting the "Grease the Wheels" hypothesis. In other words, firms located in countries that reported above average exports to Russia reported on average more instances of giving bribes if the firms believe that the court system is fair. These results proved robust to several fixed effects and alternative specifications.

Future studies will have to expand on the more detailed characteristics of countries and the role of such internal mechanisms in determining international trade relations in the first place. Such endogenous internal factors such as the degree of state capture can definitely influence external trade contracts. As such, further research will have to not only explore such internal determinants, but also their interaction with the international trading environment.

Yet, it is also necessary to understand that effective policy recommendations can only be made in the context of a very detailed understanding of each country's individual characteristics. Effective policy makers must first understand not only the theoretical, but also the individual and daily mechanism that contribute to corruption.

\section{REFERENCES}

Aidt, T Corruption, Institutions, and Economic Development, Oxford Review of Economic Policy, 25(2):271-291. 2009

Alaimo, Verónica; Pablo Fajnzylber; J. Luis Guasch; J. Humberto López; and Ana María Oviedo, "Behind the Investment Climate: Back to Basics-Determinants of Corruption. In Fajnzylber, Pablo; J. Luis Guasch; and J. Huberto López (Editors), Does the Investment Climate Matter? Microeconomic Foundations of Growth in Latin America. Washington, DC: The World Bank and Palgrave Macmillan: 139178 (Chapter 4). 2009

Blagojevic, S. and Damijan J.P. The Impact of Corruption and Ownership on the Performance of Firms in Central and Eastern Europe." Post-Communist Economies 25.2, 2013

Clark, William A., Crime and Punishment in Soviet Officialdom: Combating Corruption in the Political Elite, Armonk, N.Y.: M.E. Sharpe, 1993

Cuervo-Cazurra, Alvaro. Who Cares about Corruption? Journal of International Business Studies 37.6, 2006

J. S. Hellman, G. Jones and D. Kaufmann, 'Far From Home: Do Foreign Investors Import Higher Standards of Governance in Transition Economies?', draft paper, August 2002; P. M. Pinto and B. Zhu, Fortune or Evil? The Effect of Inward Foreign Direct Investment on Corruption, Salztman Working Paper no. 10, New York: Columbia University, 2008.

Jordan, J. M., Patronage and Corruption in the Czech Republic, in RFE/RL East European Perspectives, vol. 42002

Krueger, Anne O. The Political Economy of the Rent-Seeking Society. The American Economic Review 64.31974

Méon, P and L Weill, Is Corruption an Efficient Grease? World Development, 38(3):244259. 2010 
PricewaterhouseCoopers, Confronting Corruption: The Business Case for an Effective Anti-corruption Programme London: PricewaterhouseCoopers, 2008

Public Opinion Foundation (FOM) Socialnye resursy preodoleniya korruptsii ['Social Resources for Tackling Corruption'] 22 September 2008.

Radaev, Vadim Bureaucratic Extortion and Entrepreneurial Strategies in Russia, paper presented at Virginie Coulloudon's seminar, "The Power of Corruption," Davis Center for Russian Studies, Harvard University, 2000.

Svensson, J Who Must Pay Bribes and How Much? Evidence from a Cross Section of Firms The Quarterly Journal of Economics 118(1): 207-230. 2003

Svensson, J, Eight Questions about Corruption Journal of Economic Perspectives, 19 (3): 19-42. 2005

Transparency International, Global Corruption Report 2009 Corruption and the Private Sector Cambridge University Press 2009

Transparency International - Moldova, Corruption and Quality of Governance: The Case of Moldova Cambridge University Press 2000

Zornitsa Kutlina-Dimitrova The Economic Impact of the Russian Import Ban: A CGE Analysis, Issue 3, Dec 2013

\section{ABOUT THE AUTHOR}

Felicia Belostecinic, email: felicia.belostecinic@gmail.com

Ms. Felicia Belostecinic is currently a Research Analyst in the Research Department of the International Monetary Fund in Washington D.C., U.S.A. She graduated with a Bachelor of Science in Foreign Service in International Political Economy and a Certificate in International Development from the Edmund A. Walsh School of Foreign Service, Georgetown University. 